UDC $546.87^{\prime} 24+662^{\prime} 24$

\title{
RESEARCH INTO PHASE FORMATION AND SOME PHYSICAL AND CHEMICAL PROPERTIES OF THE $\mathrm{Sb}_{2} \mathrm{Se}_{3}$-GaSe SYSTEM ALLOYS
}

\author{
I.I. Aliyev ${ }^{1}$, N.A. Mammadova ${ }^{1}$, F.M. Sadigov ${ }^{2}$ \\ ${ }^{1}$ Acad. M.Nagiyev Institute of Catalysis and Inorganic Chemistry of ANAS, \\ 113,H. Javid Ave., AZ 1043, Baku, Azerbaijan; e-mail: aliyevimir@rambler.ru \\ ${ }^{2}$ Baku State University \\ 23, Z.Khalilov str., AZ-1148 Baku, Azerbaijan
}

Received 28.04.2019

\begin{abstract}
Behavior of interaction in the $\mathrm{Sb}_{2} \mathrm{Se}_{3}$-GaSe system was explored and a phase diagram constructed using the complex methods of physical and chemical analysis: differential thermal (DTA), $X$ ray phase (XRD), microstructural analysis (MSA), as well as the measurement of micro hardness and density. It found that in the system $\mathrm{Sb}_{2} \mathrm{Se}_{3}$-GaSe two congruently melting compounds of the $\mathrm{GaSb}_{4} \mathrm{Se}_{7}$ and $\mathrm{GaSb}_{2} \mathrm{Se}_{4}$ compositions are formed at $515^{\circ} \mathrm{C}$ and $490^{\circ} \mathrm{C}$, respectively. It revealed that the GaSe-based solubility in solid state is $4 \mathrm{~mol}$. \% Sb$b_{2} \mathrm{Se}_{3}$; but if based on $\mathrm{Sb}_{2} \mathrm{Se}_{3}$ - it is $5 \mathrm{~mol} . \% \mathrm{GaSe}$. Three eutectics are formed in the system with composition appropriate of 43 and $60 \mathrm{~mol} . \% \mathrm{Sb}_{2} \mathrm{Se}_{3}$ and melts at 470, 425 and $450^{\circ} \mathrm{C}$, respectively.
\end{abstract}

Keywords: system, congruent, eutectic, solidus, liquidus.

DOI: $10.32737 / 2221-8688-2019-3-403-407$

\section{Introduction}

It is known that chalcogenides of III B subgroup elements, as well as multicomponent phases on their basis are reputed to be perspective substances used in the development of photoelectric devices [1-3].

In literature [4-7], it is known that chancogenides of antimony $\mathrm{Sb}_{2} \mathrm{X}_{3}(\mathrm{X}-\mathrm{S}, \mathrm{Se}, \mathrm{Te})$ and solid solutions on their basis are used as materials for a p-branch of thermoelectric coolers. From this standpoint, the study of interaction between chalcogenides $\mathrm{Sb}_{2} \mathrm{Se}_{3}$ and $\mathrm{GaSe}$ is of scientific and practical significance. In literature [8-10] some systems were studied using chalcogenides of antimony.

The objective of the work is to study the phase formation and some physical and chemical properties of $\mathrm{Sb}_{2} \mathrm{Se}_{3}-\mathrm{GaSe}$ system alloys.

Note that the $\mathrm{Sb}_{2} \mathrm{Se}_{3}$ compound is obtained with open for maximums and melts congruently at $617^{\circ} \mathrm{C}$, crystallized in a rhombic syngony with lattice parameters: $a=$ 11,$633 ; b=11,780 ; c=3,985 \AA$, space group Pbnm- $D_{2 h}{ }^{16}$ density $\rho=5,843 \mathrm{~g} / \mathrm{cm}^{3}$ and micro hardness $\mathrm{H} \mu=1200 \mathrm{MPa}$ [11].

Gallium monoselenide $\mathrm{GaSe}$ melts congruently at $960^{\circ} \mathrm{C}$ and is crystallized in a hexagonal syngony with lattice parameters: $a=$ 3,$755 ; \quad c=15,94 \AA, Z=4$, space group $\mathrm{P}_{3} / \mathrm{mmc}-\mathrm{D}_{6 \mathrm{~h}}^{4}$, density $\rho=5,03 \mathrm{~g} / \mathrm{cm}^{3}$ and micro hardness $300 \mathrm{MPa}$ [12].

\section{Experimental part}

Initial components of the $\mathrm{Sb}_{2} \mathrm{Se}_{3}-\mathrm{GaSe}$ system were synthesized by melting elements of high purity in quartz ampoules vacuumed up to $0.133 \mathrm{~Pa}$ at $700-1100^{\circ} \mathrm{C}$. Note that antimony Sb-000, selenium -B4 and gallium 99.999\% were used as initial elements. To obtain equilibrium state, alloys were annealed at $400^{\circ} \mathrm{C}$ for $350 \mathrm{hrs}$.
Equilibrium alloys were studied in line with methods of differential and thermal (DTA), X-ray phase, microstructural (MSA) analyses, as well as measurement of micro hardness and determination of density.

DTA of alloys of the system was conducted using «TEMASKON-2» with a heating rate of $10 \mathrm{deg} . / \mathrm{min}$. Calibration 
chrome-aluminum thermocouple are used, $\mathrm{Al}_{2} \mathrm{O}_{3}$ is served as a standard.

$\mathrm{X}$-ray phase analysis was conducted on D2 PHASER using $\mathrm{CuK} \alpha$-radiation, Ni-filter. MSA of alloys of the system was investigated through the use of a metallographic microscope MIM-8 with GOI paste polished specimens. The microstructure was revealed by an etchant with the $\mathrm{HNO}_{3}$ (conc) composition: $\mathrm{H}_{2} \mathrm{O}_{2}=1$ : 1 . ehe etching time was $20 \mathrm{sec}$.

Micro hardness of alloys of the system was measured using PMT-3 at loads of 0.10 and $0.20 \mathrm{~N}$. Density of alloys of the system was determined using pycnometer method while toluene was used as a working liquid.

\section{Results and discussion}

Alloys of system $\mathrm{Sb}_{2} \mathrm{Se}_{3}-\mathrm{GaSe}$ are obtained in the form of light grey compact ingots. Resistance to air, water and organic solvents was studied. Strong mineral acids $\left(\mathrm{HCl}, \mathrm{HNO}_{3}\right)$ decompose them well.

Thermal analysis of the $\mathrm{Sb}_{2} \mathrm{Se}_{3}-\mathrm{GaSe}$ system alloys shows that two endothermic effects relating to solidus and liquidus were found on thermograms of alloys.

During studying microstructure of alloys of the system it found that on the basis of initial components there are limited areas of homogeneity. To determine areas of solid solutions on the basis of $\mathrm{Sb}_{2} \mathrm{Se}_{3}$, alloys containing 2, 5, 7 and $10 \mathrm{~mol} \% \mathrm{GaSe}$ were synthesized. Obtained alloys were annealed for $520 \mathrm{hrs}$. at 200 and $300^{\circ} \mathrm{C}$ and hardened in icy water. Then microstructural analysis was conducted. It revealed that the solubility on the basis of $\mathrm{Sb}_{2} \mathrm{Se}_{3}$ at room temperature is $5 \mathrm{~mol}$
$\% \mathrm{GaSe}$, but at $470^{\circ} \mathrm{C}$ it is $10 \% \mathrm{GaSe}$. Solid solutions on the basis of GaSe stretch up to 4 mol \% GaSe.

Two compounds of the $\mathrm{GaSb}_{4} \mathrm{Se}_{7}$ and $\mathrm{GaSb}_{2} \mathrm{Se}_{4}$ compositions congruently melting at 515 and $490^{\circ} \mathrm{C}$ are formed in the system $\mathrm{Sb}_{2} \mathrm{Se}_{3}-\mathrm{GaSe}$. The existence of compounds was confirmed using DTA, X-ray phase analysis, MSA analysis methods, microhardness and density measurements.

$\mathrm{On}$ thermo-grams of $\mathrm{GaSb}_{4} \mathrm{Se}_{7}$ and $\mathrm{GaSb}_{2} \mathrm{Se}_{4}$ compounds there is a single endothermic effect at 515 and $490^{\circ} \mathrm{C}$ which indicates their congruent melting. Figure 1 shows microstructure of alloys of eutectics, compounds $\mathrm{GaSb}_{4} \mathrm{Se}_{7}$ and $\mathrm{GaSb}_{2} \mathrm{Se}_{4}$. Microstructure (fig. 1 and c) of compounds $\mathrm{GaSb}_{4} \mathrm{Se}_{7}$ and $\mathrm{GaSb}_{2} \mathrm{Se}_{4}$ was studied after annealing for $750 \mathrm{hrs}$. at $450^{\circ} \mathrm{C}$.

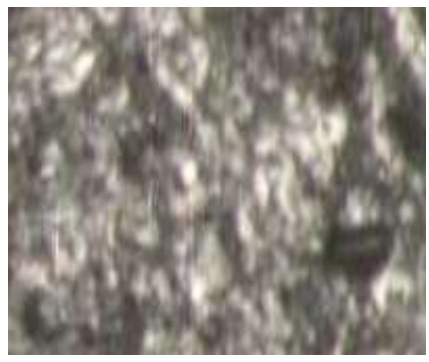

a)

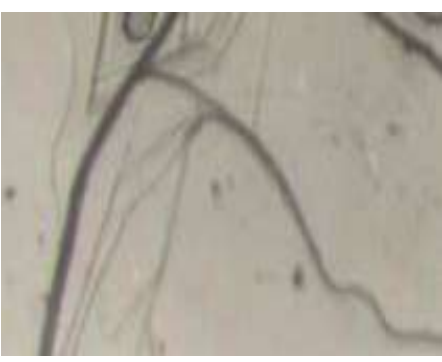

b)

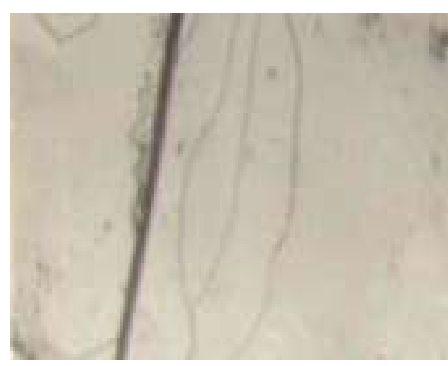

c)

Fig.1. Microstructure of eutectics (a) and $\mathrm{GaSb}_{4} \mathrm{Se}_{7}$ (b) and $\mathrm{GaSb}_{2} \mathrm{Se}_{4}$ (c) compounds. a) -15 mol. $\%$ GaSe (eutectics), b)- $\left.\mathrm{GaSb}_{4} \mathrm{Se}_{7}, \mathrm{c}\right)-\mathrm{GaSb}_{2} \mathrm{Se}_{4}$.

According to X-ray phase analysis, inter-planar distances and intensities of diffraction peaks of initial alloys 20;33,33; 50 and $70 \mathrm{~mol} . \%$ GaSe (Fig.2) were calculated. It found that diffraction peaks of alloys $33.33 ; 50$ mol \% GaSe revealed on diffraction pattern differ from diffraction peaks of initial compounds. 

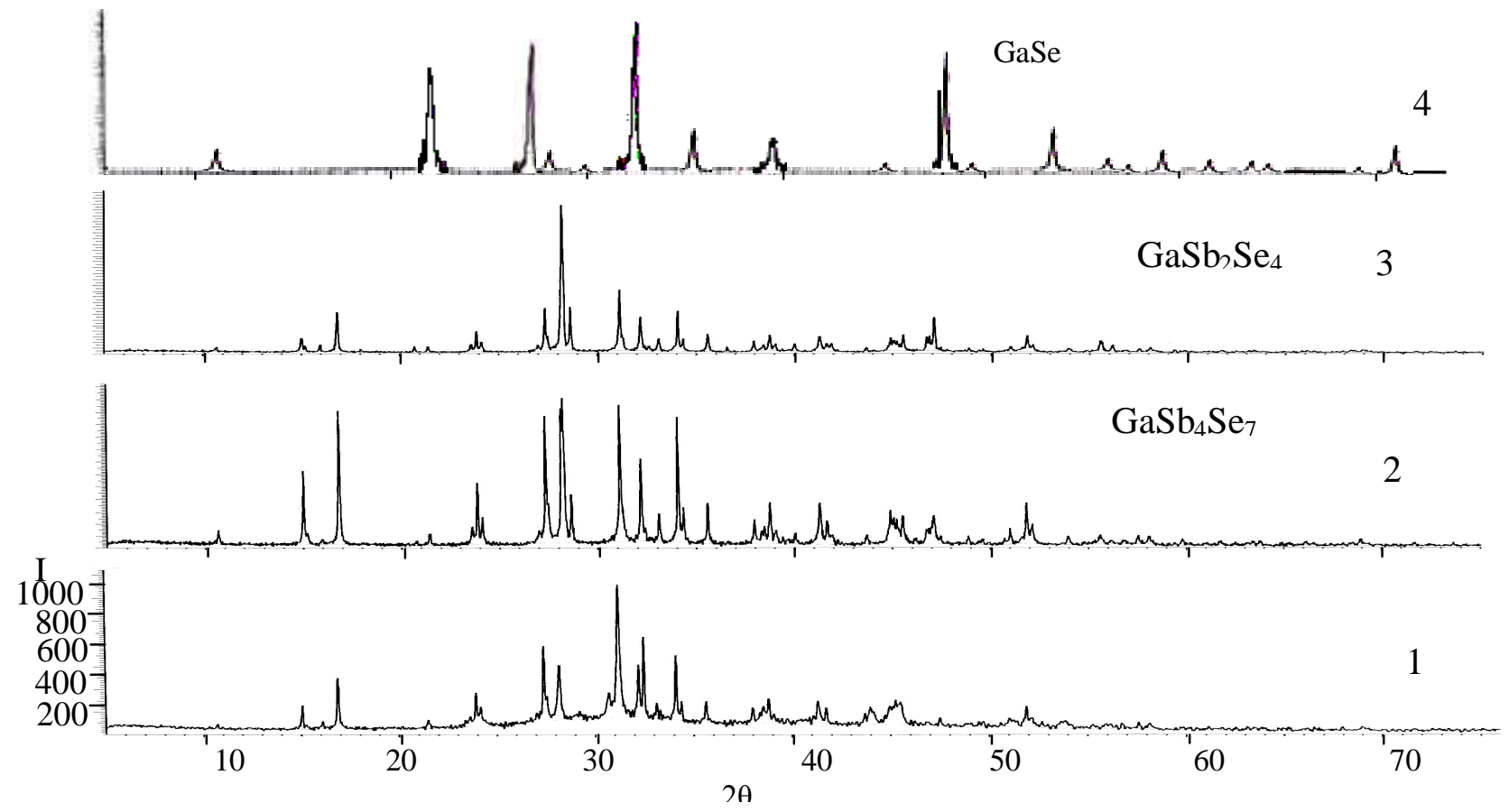

Fig.2. Diffractograms of alloys of the system $\mathrm{Sb}_{2} \mathrm{Se}_{3}-\mathrm{GaSe}$.

1- $\mathrm{Sb}_{2} \mathrm{Se}_{3} 2-20,3-33,33\left(\mathrm{GaSb}_{4} \mathrm{Se}_{7}\right), 4-50\left(\mathrm{GaSb}_{2} \mathrm{Se}_{4}\right), 5-70$, 6- $100 \mathrm{~mol} . \%$ GaSe.

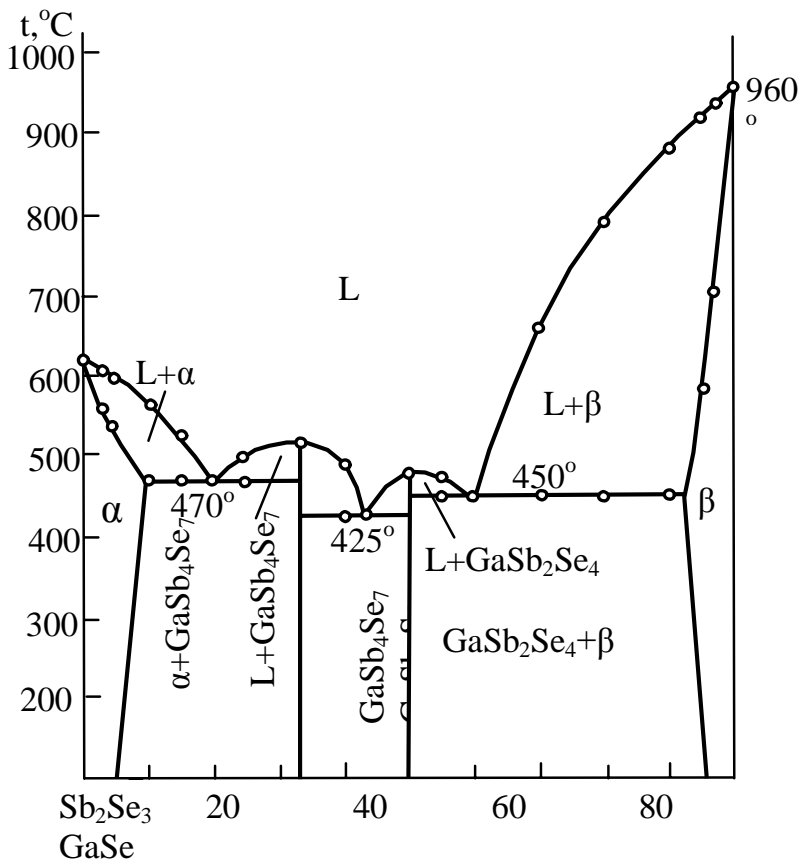

Fig. 3. Phase diagram of the $\mathrm{Sb}_{2} \mathrm{Se}_{3}-\mathrm{GaSe}$ system.

According to physical and chemical analysis, the state diagram of the $\mathrm{Sb}_{2} \mathrm{Se}_{3}-\mathrm{GaSe}$ system was constructed (Fig. 3). Part of liquidus in the concentration range of $0-20 \mathrm{~mol}$ $\%$ GaSe corresponds to primary separation of $\alpha$-phase (solid solutions based on $\mathrm{Sb}_{2} \mathrm{Se}_{3}$ ), concentration limits of 20-43 mol \% GaSe crystals of new phase $\mathrm{GaSb}_{4} \mathrm{Se}_{7}$ are separated from liquid, primary crystallization of the phase $\mathrm{GaSb}_{2} \mathrm{Se}_{4}$ occurs in the range of $43-60$ mol \% GaSe, finally, $\beta$-phases (solid solutions based on GaSe) are crystallized in concentration range of 60-100 mol \% GaSe .

It should be added that microhardness of alloys in the system was measured using PMT-3 loaded up to 0.15 N. Results of micro 
hardness measurement of alloys are cited in Table to show that four rows of values are found in the system. For the $\alpha$-phase, the microhardness varies within (1200-1250) $\mathrm{MPa}$. In the concentration range of 20-43 mol. $\%$ GaSe a new value of microhardness (13501400) $\mathrm{MPa}$ is revealed to indicate the microhardness of the new phase GaSb4Se7. In the range of 43-60 mol. \% GaSe the microhardness value (1500-1530) $\mathrm{MPa}$ is in accord with the new GaSb2Se4 phase. For the GaSe compound, the microhardness values are $300 \mathrm{MPa}$.

Table. Results of DTA, measurement of micro hardness and density of the $\mathrm{Sb}_{2} \mathrm{Se}_{3}-\mathrm{GaSe}$ system alloys

\begin{tabular}{|c|c|c|c|c|c|c|c|}
\hline \multicolumn{2}{|c|}{ Composition, mol \% } & \multirow{3}{*}{ Thermal effects, ${ }^{\circ} \mathrm{C}$} & \multirow{3}{*}{$\begin{array}{l}\text { Density, } \\
10^{3} \mathrm{~kg} / \mathrm{m}^{3}\end{array}$} & \multicolumn{4}{|c|}{ Micro hardness of phases, MPa } \\
\hline \multirow{2}{*}{$\mathrm{Sb}_{2} \mathrm{Se}_{3}$} & \multirow{2}{*}{ GaSe } & & & $\alpha$ & $\mathrm{GaSb}_{4} \mathrm{Se}_{7}$ & $\mathrm{GaSb}_{2} \mathrm{Se}_{4}$ & $\beta$ \\
\hline & & & & \multicolumn{3}{|c|}{$\mathrm{P}=0,15 \mathrm{H}$} & \\
\hline 100 & 0.0 & 617 & 5.84 & 1200 & - & - & - \\
\hline 97 & 3.0 & 560,610 & 5.82 & 1230 & - & - & - \\
\hline 95 & 5.0 & 520,590 & 5.80 & 1250 & - & - & - \\
\hline 90 & 10 & 470,565 & 5.74 & 1250 & - & - & - \\
\hline 85 & 15 & 470,520 & 5.68 & - & - & - & - \\
\hline 80 & 20 & 570 & 5.65 & Eutec. & Eutec. & - & - \\
\hline 75 & 25 & 470,500 & 5.64 & - & - & - & - \\
\hline 70 & 30 & 470,510 & 5.60 & - & 1350 & - & - \\
\hline 66,6 & 33.3 & 515 & 5.63 & - & 1400 & - & - \\
\hline 60 & 40 & 425,480 & 5.55 & - & 1400 & - & - \\
\hline 57 & 43 & 425 & 5.50 & - & Eutec. & Eutec. & - \\
\hline 50 & 50 & 490 & 5.52 & - & - & 1500 & - \\
\hline 45 & 55 & 450,475 & 5.41 & & - & 1530 & - \\
\hline 40 & 60 & 450 & 5.35 & - & - & Eutec. & Eutec. \\
\hline 30 & 70 & 450,655 & 5.23 & - & - & - & 370 \\
\hline 20 & 80 & 450,770 & 5.19 & - & - & - & 370 \\
\hline 10 & 90 & 450,875 & 5.16 & - & - & - & 370 \\
\hline 5,0 & 95 & 580,940 & 5.12 & - & - & - & 370 \\
\hline 3,0 & 97 & 700,945 & 5.08 & - & - & - & 350 \\
\hline 0,0 & 100 & 960 & 5.03 & - & - & - & 300 \\
\hline
\end{tabular}

\section{References}

1. Tagiev B.G., Tagiev O.B., Ibragimov Z.A., Abushov S.A., Eyyubov G.Yu. Luminescence of layered GaS: Er and GaS: Er, Yb crystals. Fizika. 2007, vol. XIII, no. 1-2, pp. 292-294. (In Azerbaijan).

2. Abdinov A.Sh., Kazymzade A.G. Infrared quenching of residual photoconductivity in gallium selenide single crystals. Semiconductors/physics of the solid state, 1978, no.12, p.1237.

3. Shigetomi S., Ikari T. Optical and electrical characteristics of $\mathrm{p}-\mathrm{GaSe}$ doped with Te. $J$. Appl. Phys. 2004, vol. 9, no. 11, pp. 6480-6482.

4. Fernandez A.M., Merino M.G. Preparation and characterization of $\mathrm{Sb}_{2} \mathrm{Se}_{3}$ thin films prepared by electrodeposition for photovoltaic applications. Thin Solid Films. 2000, vol. 366, no. 1-2, pp. 202-206.

5. Ivanova L.D., Granatkina Yu. V. Thermoelectric properties of $\mathrm{Bi}_{2} \mathrm{Te}_{3}-\mathrm{Sb}_{2} \mathrm{Te}_{3}$ single crystals in the range of 100-700 K. Inorganic Materials. 2000, vol. 36, no. 7, pp. 672-675.

6. Ivanova D., Petrova I., Granatkina Yu.V., Zemskov V.S. Thermoelectric materials based on $\mathrm{Sb}_{2} \mathrm{Te}_{3}-\mathrm{Bi}_{2} \mathrm{Te}_{3}$ solid solutions with optimal performance in the range of 100-400 K. Inorganic Materials. 2007, vol. 43, no. 9, pp. 933-936.

7. Magomedov A.Z., Aliev A.O., Aslanov M.A., Musaeva S.M., Javadova S.D. Peculiarities of the temperature dependence of the spectral distribution of photosensitivity of $\mathrm{Sb}_{2} \mathrm{~S}_{3}-\mathrm{Sb}_{2} \mathrm{Se}_{3}$ 
ferroelectric semiconductors. Baku university news. 2004, no. 4, pp.163-169. (In Azerbaijan).

8. Aliyev I.I., Jafarova G.Z., Aliyev F.H., Shahuseynov T.F. Phase equilibrium in the $\mathrm{Sb}_{2} \mathrm{~S}_{3}-\mathrm{In}_{3} \mathrm{Sb}_{2} \mathrm{~S}_{3} \mathrm{Se}_{3}$ system. Chemical Problems. 2010, no. 4, pp. 635-639.

9. Ismailov F.I., Aliev I.I., Aliev I.P. Synthesis and physicochemical study of $\mathrm{P}$ type solid solutions $\left(\mathrm{Sb}_{2} \mathrm{Te}_{3}+\mathrm{Bi}_{2} \mathrm{Te}_{3}+\mathrm{Se}+\mathrm{Te}\right)_{1-\mathrm{x}}(\mathrm{Sm})_{\mathrm{x}}$. Chemical Problems. 2008, no. 2, pp. 357-358.

10. Ismay1lov F.I., Aliyev I.I., Aliyev A.A. The effect of Pr on the physico-chemical properties of a solid solution $\left(\mathrm{Sb}_{2} \mathrm{Te}_{3}+\mathrm{Bi}_{2} \mathrm{Te}_{3}+\mathrm{Se}+\mathrm{Te}\right)_{1 \text { - }}$ x of p type. Chemical Problems. 2008, no. 1, pp. 163-164.

11. State diagrams of binary metal systems. Reference, vol.3. Under. Ed. Lyakisheva N.P. Moscow : Engineering Publ., 2001, 872 p.

12. Luzhnaya N.P., Babaeva P.K., Rustamov P.G. The state diagram of the Ga-Se system and the properties of the phases formed. In the book "New Semiconductor Materials". Baku: Elm Publ., 1972, pp. 27-32.

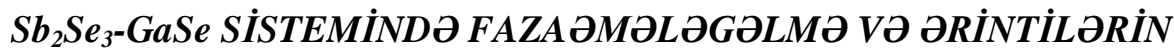 FIZIKI-KIMYӘVI XASSӘLӘRININ TəDQIQI
}

\author{
I.I. Oliyev ${ }^{1}$, N.A. Mommədova ${ }^{1}$, F.M. Sadıqov ${ }^{2}$ \\ ${ }^{1}$ AMEA-nın acad. M.Nağlyev ad. Kataliz vo Qeyri-Üzvi Kimya İnstitutu \\ AZ 1043, Bakl, H. Cavid pr.113; e-mail: aliyevimir@ rambler.ru \\ ${ }^{2}$ Bakl Dövlat Universiteti \\ AZ-1148 Baku, Z.Xəlilov küç., 23
}

Fiziki-kimyəvi analizin kompleks metodlarl: diferensial-termiki (DTA), rentgenfaza (RFA), mikroquruluş (MQA) analizi va elaca da mikrobərkliyin va sixlı̆̆ın tayini vasitasila $\mathrm{Sb}_{2} \mathrm{Se}_{3}$-GaSe sistemi tadqiq edilmis və faza diaqramı qurulmuşdur. Müəyyən edilmişdir ki, $\mathrm{Sb}_{2} \mathrm{Se}_{3}-\mathrm{GaSe}$ sistemində iki - $\mathrm{GaSb}_{4} \mathrm{Se}_{7}$ və $\mathrm{GaSb}_{2} \mathrm{Se}_{4}$ tarkibli uyğun olaraq, $515^{\circ} \mathrm{C}$ va $490^{\circ} \mathrm{C}$-do konqruyent ariyan birlaşmalar alınmuşdır. Sistemda GaSe asasında $4 \mathrm{~mol} \mathrm{\%} \mathrm{Sb}_{2} \mathrm{Se}_{3}$ hall olduğu halda, $\mathrm{Sb}_{2} \mathrm{Se}_{3}$ birlaşmasi asasinda isa $5 \mathrm{~mol} \% \mathrm{GaSe}$ hall olduğu aşkar edilmişdir. Sistemdə amala galan üç evtektikanın tarkibi 20; 43 u $60 \mathrm{~mol} \% \mathrm{Sb}_{2} \mathrm{Se}_{3}$, temperaturlart isa uyğun olaraq 470,425 u $450^{\circ} \mathrm{C}$-dir.

Açar sözlor: sistem, konqruyent, evtektika, solidus, likvidus.

\section{ИССЛЕДОВАНИЕ ФАЗООБРАЗОВАНИЯ И НЕКОТОРЫХ ФИЗИКО- ХИМИЧЕСКИХ СВОЙСТВ СПЛАВОВ СИСТЕМЫ Sb $\mathrm{Se}_{3}$-GaSe}

\author{
И.И. Алиев ${ }^{1}$ Н.А. Мамедова ${ }^{1}$ Ф.М. Садыгов ${ }^{2}$ \\ ${ }^{1}$ Институт катализа и неорганической химии Национальной АН Азербайджана \\ AZ 1043 Баку, пр.Г.Джавида,113; e-mail: aliyevimir@rambler.ru \\ ${ }^{2}$ Бакинский государственный университет \\ AZ-1148 Баку, у. 3. Халилова, 23
}

Комплексными методами физико-химического анализа: дифференииально-термического (ДТА), рентгенофазового (РФА), микроструктурного (МСА) анализа, а также измерением микротвердости и плотности изучен характер взаимодействия в системе $\mathrm{Sb}_{2} \mathrm{Se}_{3}$-GaSe $и$ построена фазовая диаграмма. Установлено, что в системе $\mathrm{Sb}_{2} \mathrm{Se}_{3}$-GaSe образуются два конгруэнтно плавящихся соединения $\mathrm{GaSb}_{4} \mathrm{Se}_{7}$ и $\mathrm{GaSb}_{2} \mathrm{Se}_{4}$ при температурах $515^{\circ} \mathrm{C}$ и $490^{\circ} \mathrm{C}$ соответственно. Установлено, что растворимость на основе GaSe в твердом состоянии составляет 4 мол. \% $\mathrm{Sb}_{2} \mathrm{Se}_{3}$, а на основе $\mathrm{Sb}_{2} \mathrm{Se}_{3}-5$ мол. \% GaSe. В системе образуются три эвтектики, состав которых отвечает 20; 43 и 60 мол. \% $\mathrm{Sb}_{2} \mathrm{Se}_{3}$ при температурах 470, 425 и $450^{\circ} \mathrm{C}$ соответственно.

Ключевые слова: система, конгруэнтный, эвтектика, солидус, ликвидус. 